\title{
Effect of Mycobacterium tuberculosis and its components on macrophages and the release of matrix metalloproteinases
}

\author{
Jui C Chang,* Annette Wysocki, Kam-Meng Tchou-Wong, Naomi Moskowitz, \\ Yihong Zhang, William N Rom
}

\begin{abstract}
Background - Pulmonary tuberculosis is associated with caseating necrosis, parenchymal lung destruction, and cavity formation. It was hypothesised that tuberculous lung destruction is mediated, at least in part, by the participation of matrix metalloproteinases released by mononuclear phagocytes.

Methods - Cells of the myelomonocytic leukaemia cell line THP-1 were incubated with lipoarabinomannan (LAM), the major antigenic cell wall component, and with Mycobacterium tuberculosis and analysed by Northern blot analysis. Two patients with active cavitary tuberculosis also underwent bronchoalveolar lavage and the cells were analysed by Northern blotting.
\end{abstract}

Results - Incubation of THP-1 cells with LAM resulted in the stimulated release of matrix metalloproteinase-9 (MMP-9), a $92 \mathrm{kDa}$ gelatinase, by 24 hours in a dosedependent fashion. In addition, Northern analysis revealed that LAM upregulated the gene for MMP-9 by 24 hours, but not the gene for the $72 \mathrm{kDa}$ gelatinase MMP2. Heat killed $M$ tuberculosis H37Ra also upregulated the MMP-9 gene. Bronchoalveolar lavage of the two patients with active cavitary tuberculosis showed striking upregulation of the MMP-9 gene compared with a normal control using Northern analysis. LAM also upregulated the type I interstitial collagenase (MMP1) gene by 24 hours in both THP-1 cells and peripheral blood monocytes.

Conclusions - These data suggest that $M$ tuberculosis and its major cell antigenic component, LAM, stimulate the release of MMP-9 and upregulate the expression of genes for MMP-1 and MMP-9. It is possible that $M$ tuberculosis and its components contribute directly to cavity formation by their ability to stimulate macrophages to release matrix metalloproteinases that digest collagens I-IV, and indirectly by stimulating the release of the cytokines interleukin $1 \beta$ and tumour necrosis factor $\alpha$ that induce fibroblasts to amplify the release of matrix metalloproteinases.

(Thorax 1996;51:306-311)

Keywords: collagenases, matrix metalloproteinases, tuberculosis, cavity.

Central caseating necrosis is the hallmark of tuberculous granulomas. Tissue caseation leads to destruction of lung tissue with cavity formation. The granulomatous lesion is tyically a cell mediated response involving macrophages and lymphocytes as the immunoresponsive cells. Fibroblasts, one of the major connective tissue cells, are also involved in the course of the acute and chronic phase of granulomatous inflammation as evidenced by the deposition of collagen fibres in the granulomatous lesion. ${ }^{1}$ Advanced pulmonary tuberculosis is associated with a locally destructive process of cavitary lesions which plays an important part in transmission of disease. The pathogenesis of the destructive lung disease caused by Mycobacterium tuberculosis is still poorly understood. Dannenberg ${ }^{2}$ suggested that the tissue damage such as liquefaction, caseation, and cavity formation was the result of a hypersensitivity reaction - that is, excess bacillary antigen causing host tissue or cells to produce cytotoxic cytokines, oxygen radicals, hydrolytic enzymes and eventual cell death. ${ }^{3}$ Since the degradation of connective tissue matrix involves an initial extracellular cleavage of insoluble proteins mediated by neutral proteinases such as elastases and collagenases, ${ }^{4}$ it would be important to assess neutral matrix metalloproteinase activity in host cells during tuberculosis infection. ${ }^{5}$ To test the hypothesis that $M$ tuberculosis or its components modulate the synthesis of matrix metalloproteinases, especially collagenases, we have studied the effects of $M$ tuberculosis and lipoarabinomannan (LAM), the major antigenic component of the mycobacterial cell wall, ${ }^{67}$ on the stimulation of matrix metalloproteinases in human peripheral blood monocytes and a myelomonocytic leukaemia cell line (THP-1). ${ }^{7}$ Bronchoalveolar lavage (BAL) was also performed in two patients with active cavitary tuberculosis to obtain BAL cells to assess expression of the matrix metalloproteinase- 9 gene. Since we ${ }^{8}$ and others ${ }^{9-13}$ have shown that LAM can stimulate the release of tumor necrosis factor $\alpha$ (TNF- $\alpha$ ) and interleukin $1 \beta$ (IL$1 \beta$ ) from mononuclear phagocytes, and since these two cytokines are known to stimulate collagenase production in synovial cells, ${ }^{1415}$ we evaluated gene expression of the type $I$ interstitial collagenase following stimulation of human lung fibroblasts.

\section{Methods}

CELL CULTURE AND STIMULATION

Lipoarabinomannan (LAM) from laboratory attenuated Mycobacterium spp was kindly provided by Dr P Brennan, Fort Collins, Colorado, 
USA. Evaluation of tuberculosis reagents for the presence of Gram negative bacterial endotoxin was performed with the amoebocyte lysate assay (E-Toxate Kit, Sigma). A lipopolysaccharide (LPS) standard curve was generated with an assay limit of $1 \mathrm{pg} / \mathrm{ml}$ LPS. Six different batches of LAM from $M y c o-$ bacterium spp were tested and all contained $<5 \mathrm{pg} / \mathrm{ml} \mathrm{LPS}$ or $<5 \mathrm{pg} / \mu \mathrm{g}$ test reagent. The LAM had been passed through a Detoxigel column to remove any potential LPS. Lipopolysaccharide from Escherichia coli was purchased from Sigma; $M$ tuberculosis H37Ra (heat killed) was obtained from American Type Culture Collection (ATCC), Rockville, Maryland; human lung fibroblasts (CCL 190) and the myelomonocytic leukaemia cell line (THP-1) were obtained from ATCC; human collagenase cDNA (pC11 ase 1) was obtained from ATCC and was cloned from TPA treated human skin fibroblasts from a healthy 29 year old man; the $92 \mathrm{kDa}$ and $72 \mathrm{kDa} \mathrm{cDNAs}$ for matrix metalloproteinases were a gift of Dr Gregory Goldberg, Washington University, St Louis, Missouri; and the pHe 7 cDNA probe was used as a control housekeeping gene.

THP-1 cells were grown in RPMI 1640 medium at $37^{\circ} \mathrm{C}, 95 \%$ air $/ 5 \%$ carbon dioxide supplemented with $10 \%$ fetal calf serum and $100 \mathrm{U} / \mathrm{ml}$ penicillin plus $100 \mu \mathrm{g} / \mathrm{ml}$ streptomycin. Peripheral blood monocytes were isolated from human buffy coat obtained from tuberculin negative individuals. Mononuclear cells were isolated from blood components by lymphocyte separation medium (LSM, Teknita Corp, Durham, North Carolina), centrifuged and washed three times with RPMI 1640. Mononuclear cells were then suspended in RPMI supplemented with $10 \%$ fetal calf serum and antibiotics. The cells were plated in a $250 \mathrm{ml}$ culture flask at $2 \times 10^{6}$ cells $/ \mathrm{ml}$. After allowing the cells to adhere for 1.5 hours at $37^{\circ} \mathrm{C}$ the cells were washed three times with ice cold phosphate buffered saline (PBS). The adherent cells, which consisted of more than 95\% monocytes, were exposed to test reagents for up to 24 hours in serum-free media.

Human lung fibroblasts were cultured at $37^{\circ} \mathrm{C}$ in humidified $90 \%$ air $/ 10 \%$ carbon dioxide in DMEM supplemented with $10 \%$ fetal calf serum and penicillin plus streptomycin. At confluence, fibroblasts were treated with IL$1 \alpha(5 \mathrm{U} / \mathrm{ml})$ or $\mathrm{TNF}-\alpha(10 \mathrm{ng} / \mathrm{ml})$ in serumfree medium.

\section{BRONCHOALVEOLAR LAVAGE}

Bronchoalveolar lavage was performed with a flexible fibreoptic bronchoscope with local xylocaine anesthaesia. Normal saline $(3 \times 50 \mathrm{ml}$ aliquots) was instilled into the radiographically involved site in tuberculosis patients, and $5 \times 20 \mathrm{ml}$ aliquots were instilled in three different sites and pooled for the normal volunteer. The recovered fluid was filtered through sterile gauze. A total cell count was performed in a haematocytometer and cell viability was determined by trypan blue exclusion. Bronchoalveolar lavage cells were immediately placed in $5.5 \mathrm{M}$ guanidinium isothiocyanate buffer and frozen at $-70^{\circ} \mathrm{C}$. Two patients with active pulmonary tuberculosis confirmed by sputum culture of $M$ tuberculosis with radiographic cavities and one normal volunteer were lavaged. All three individuals were HIV negative and both patients with active tuberculosis had received isoniazid, rifampicin, pyrazinamide, and ethambutol for two weeks before lavage. The clinical research protocol had been approved by the human subjects review committees of New York University Medical Center and Bellevue Hospital.

\section{NORTHERN ANALYSIS}

Preparation of total RNA from monocytes, THP-1 cells, or bronchoalveolar lavage cells was carried out according to the guanidinium isothiocyanate method. Briefly, cells were washed three times and lysed by $5.5 \mathrm{M}$ guanidinium solution containing $5 \mathrm{mM}$ sodium citrate, $0.5 \%$ Sarkosyl, and $1 \% \beta$-mercaptoethanol. The RNA was then pelleted through a caesium chloride gradient and dissolved in RNA suspension buffer $(0.5 \%$ SDS, $10 \mathrm{mM}$ EDTA, $10 \mathrm{mM}$ Tris pH $8 \cdot 0,0 \cdot 2 \mathrm{M} \mathrm{NaCl}$ ).

Electrophoresis of the sample was performed in a $1 \%$ agarose $/ 7 \%$ formaldehyde gel and the gel was transferred to a NYTRAN membrane (Schleicher and Schuell, Keene, New Hampshire, USA) by capillary blotting. NYTRAN filters were hybridised with respective cDNAs labelled with ${ }^{32} \mathrm{P}$ using random primer labelling (Boehringer Mannheim). Hybridisations were carried out for 20 hours at $42^{\circ} \mathrm{C}$ and washing was performed three times for 30 minutes in $2 \times \mathrm{SSC} / 0 \cdot 1 \% \mathrm{SDS}$ at $22^{\circ} \mathrm{C}$ and then twice for 30 minutes in $0.1 \times \mathrm{SSC} / 0.1 \%$ SDS at $65^{\circ} \mathrm{C}$. Filters were exposed to Kodak X-Omat AR film with intensifying screens at $-70^{\circ} \mathrm{C}$ for 2-8 days.

\section{SUBSTRATE GEL ELECTROPHORESIS}

Proteinase profiles were determined by substrate gel electrophoresis using $8 \%$ acrylamide gels containing gelatin at a final concentration of $4.75 \mathrm{mg} / \mathrm{ml} .^{16}$ Conditioned media from THP-1 cells that had been stimulated with varying concentrations of LAM or LPS ( $500 \mathrm{pg} / \mathrm{ml}, 1 \mathrm{ng} / \mathrm{ml}, 500 \mathrm{ng} / \mathrm{ml}, 1 \mu \mathrm{g} / \mathrm{ml}$ ) were subjected to SDS-PAGE under non-reducing conditions at $22^{\circ} \mathrm{C}$. Each lane was loaded with $30 \mu \mathrm{g}$ protein. After electrophoresis the gels were washed twice for 30 minutes with $2 \cdot 5 \%$ Triton-X-100 to remove SDS. Gels were then briefly rinsed with deionised water and then incubated overnight at $37^{\circ} \mathrm{C}$ in buffer containing $50 \mathrm{mM}$ Tris $\mathrm{HCl}, 150 \mathrm{mM} \mathrm{NaCl}$, and $5 \mathrm{mM} \mathrm{CaCl}_{2}$ (pH 7.4). Following incubation, gels were stained with $0 \cdot 1 \%$ Coomassie brilliant blue and destained. Proteolytic activity appeared as clear zones against a dark blue background.

\section{Results}

DEMONSTRATION OF MMP-9 AND MMP-2 Substrate gel electrophoresis demonstrated a gelatinase with an apparent molecular mass of 


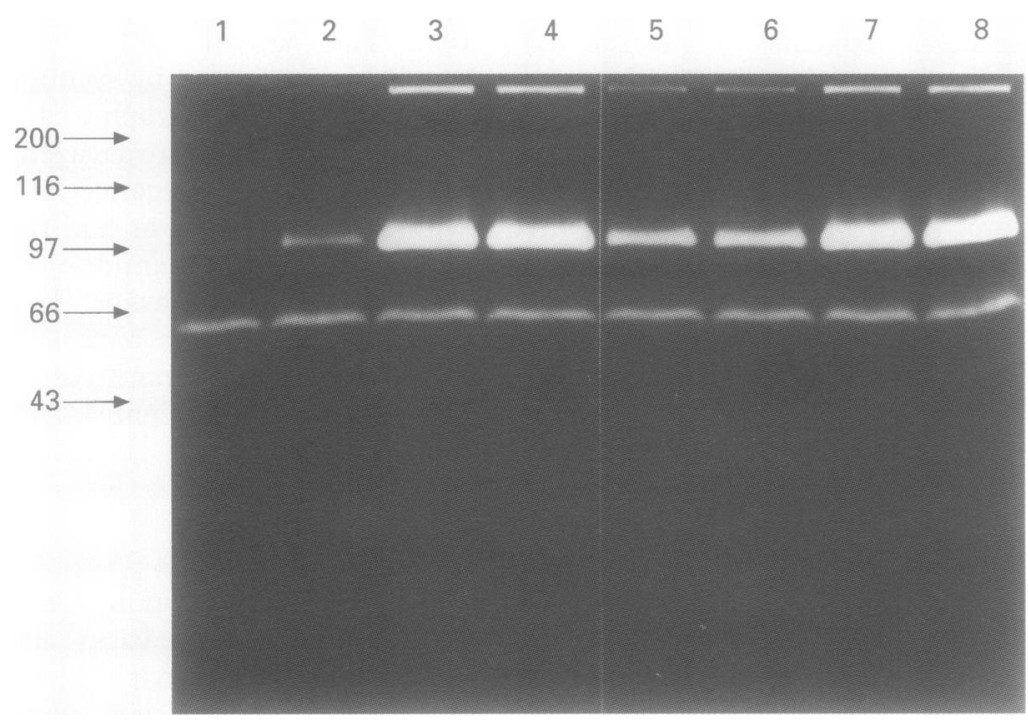

Figure 1 Substrate gel electrophoresis of conditioned media collected at 24 hours from THP-1 cells. Lane 1, medium alone (negative control); lane 2, LAM (500 pg/ml); lane 3, LAM (500 ng/ml); lane 4, LAM (1 $\mathrm{gg} / \mathrm{ml})$; lane 5, LPS (500 pg/ml); lane 6, LPS (1 $\mathrm{ng} / \mathrm{ml})$; lane 7, LPS (500 $\mathrm{ng} / \mathrm{ml})$; lane 8, LPS (1 $\mathrm{\mu g} / \mathrm{ml})$. Molecular weight markers $(k D a)$ are indicated along the margins.

$92 \mathrm{kDa}$ that was stimulated by LAM and LPS in supernatants from THP-1 cells. The $92 \mathrm{kDa}$ gelatinase (MMP-9) was barely detectable by two hours (data not shown) but was prominent at 24 hours (fig 1). A dose-response analysis revealed that the gelatinase was discernible at LAM doses of $500 \mathrm{pg} / \mathrm{ml}$ and maximally stimulated at $500 \mathrm{ng} / \mathrm{ml}$. Other matrix metalloproteinases detected in the THP-1 supernatants were a $230 \mathrm{kDa}$ gelatinase which may be a higher molecular weight aggregate of MMP-9. The $72 \mathrm{kDa}$ gelatinase (MMP-2) was constitutively expressed.

NORTHERN ANALYSIS OF MMP-9 AND MMP-2 Incubation of THP-1 cells for 24 hours with LAM $(2 \mu \mathrm{g} / \mathrm{ml})$ or LPS $(1 \mu \mathrm{g} / \mathrm{ml})$ revealed upregulation of MMP-9 by LAM or LPS by 24 hours in comparison with the unstimulated control (fig 2); there was no detectable upregulation at two hours. Equal amounts of total RNA were loaded in each lane as shown by the pHe 7 housekeeping gene. These data are consistent with the increased protein release and time course after LAM or LPS stimulation of THP-1 cells by substrate gel electrophoresis. MMP-2 was constitutively expressed at the gene level (fig 2), similar to the observation made with the zymogram.

Incubation of THP-1 cells with $M$ tuberculosis H37Ra (heat killed) revealed upregulation of MMP-9 similar to that with LPS (fig 3).

Northern analysis of bronchoalveolar lavage cells from two patients with active cavitary pulmonary tuberculosis and one normal volunteer demonstrated striking upregulation of the gene for MMP-9 in both tuberculosis patients compared with the normal volunteer (fig 4). A small amount of constitutive expression of MMP-9 could be detected in the normal volunteer and equal amounts of total RNA were loaded in each lane as demonstrated by the $\beta$ actin housekeeping gene.

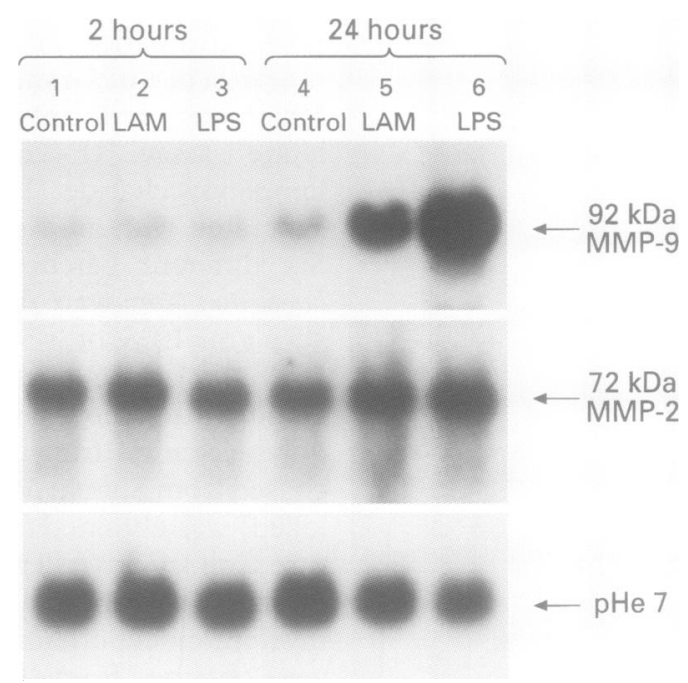

Figure 2 Northern analysis of $92 \mathrm{kDa}$ and $72 \mathrm{kDa}$ matrix metalloproteinases (MMP-9 and MMP-2). THP1 cells were incubated with LAM $(2 \mu \mathrm{g} / \mathrm{ml})$ or LPS $(1 \mu \mathrm{g} /$ ml) for two hours (lanes 1-3) or 24 hours (lanes 4-6). Lanes 1 and 4, unstimulated cells; lanes 2 and 5, LAM; lanes 3 and 6, LPS.

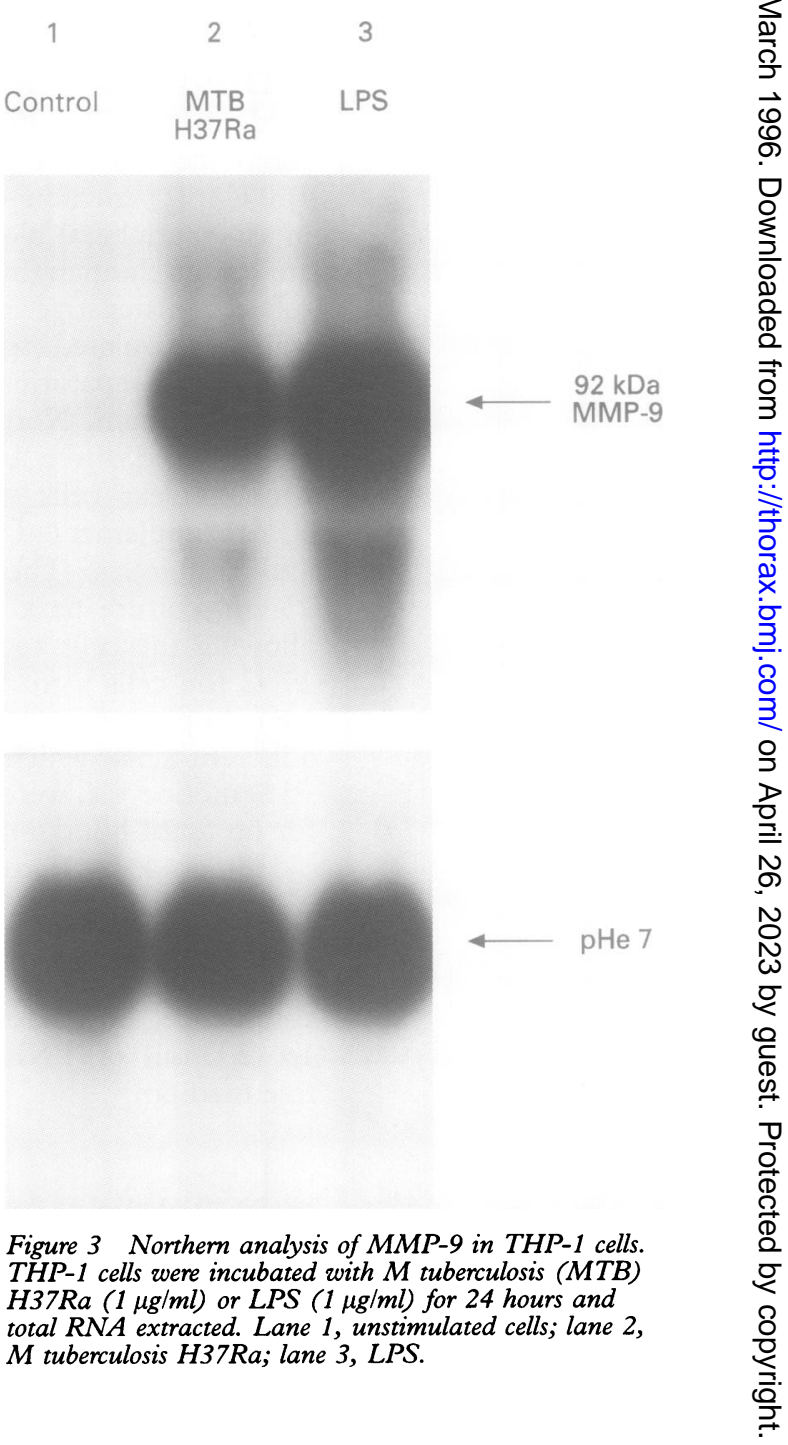

NORTHERN ANALYSIS OF MMP-1

Incubation of THP-1 cells with LAM induced an increase in type I interstitial collagenase (MMP-1) mRNA compared with unstimulated cells as early as two hours (fig 5A) and was significantly upregulated at 24 hours (fig 5B) and persisted up to 48 hours of incubation. 


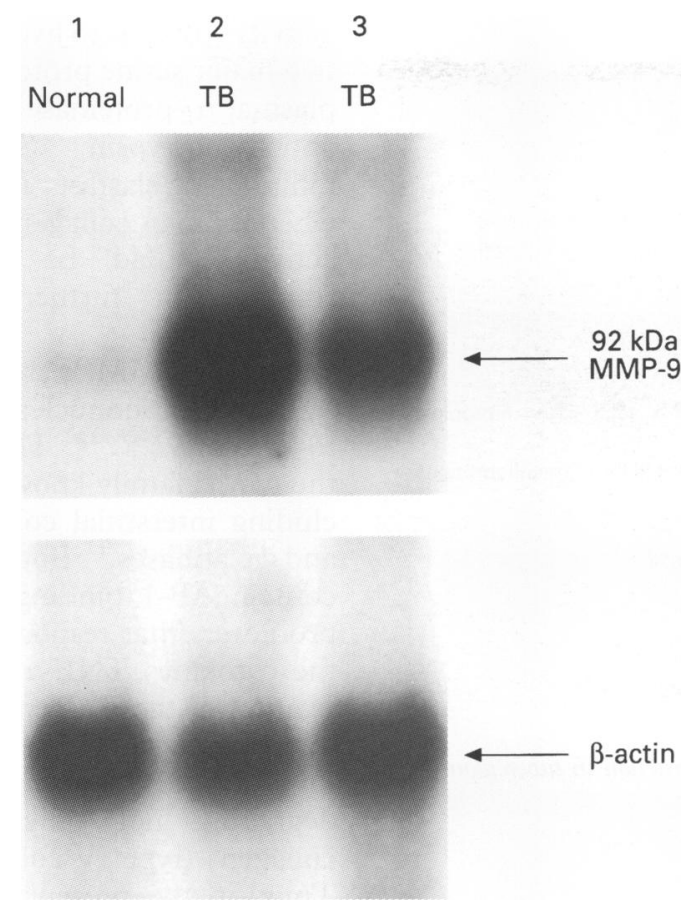

Figure 4 Northern analysis of bronchoalveolar lavage (BAL) cells. Total RNA from BAL cells was run on an agarose-formaldehyde gel and filters were probed with $M M P-9 c D N A$. Lane 1, normal volunteer; lanes 2 and 3, tuberculosis patients.

Equal amounts of RNA were loaded in each lane as demonstrated by ethidium bromide staining of the gel. The ability of LAM to induce MMP-1 mRNA expression was similar to that with LPS. Incubation of peripheral blood monocytes with LAM induced an increase in MMP-1 mRNA at 24 hours (fig 6). Ethidium bromide stained gels demonstrated equal amounts of RNA in each lane. Incubation of human lung fibroblasts with TNF- $\alpha$, IL-

A

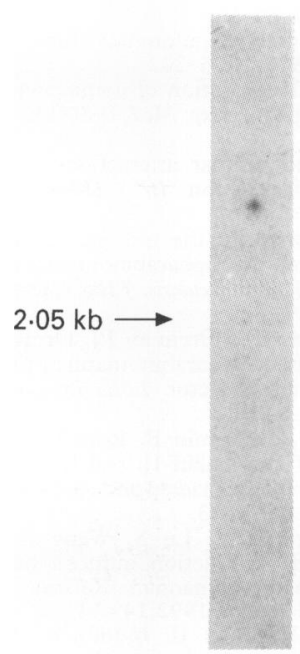

Control

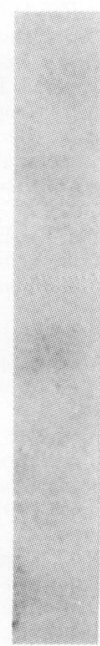

LPS
B

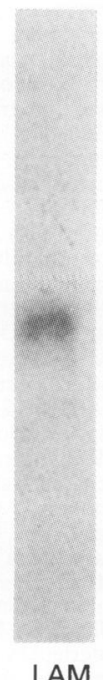

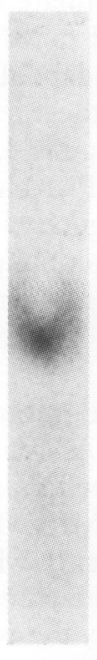

LPS

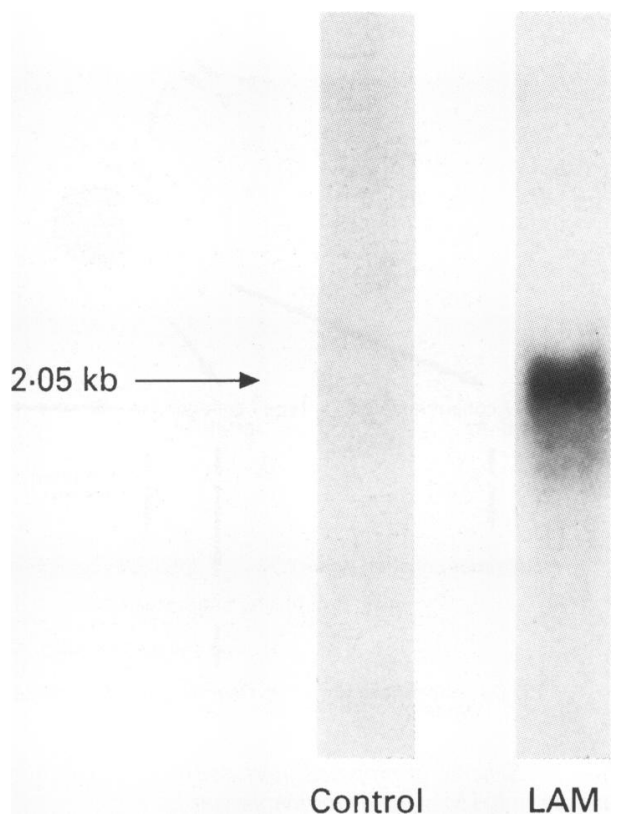

Figure 6 Analysis of steady state MMP-1 mRNA levels in peripheral blood monocytes. Human peripheral blood monocytes were stimulated for 24 hours with LAM (2 $\mu \mathrm{g}$ ) $\mathrm{ml})$ and equal amounts of total $R N A(35 \mu \mathrm{g})$ were extracted as determined by ethidium bromide gel staining.

$1 \alpha$, or tetradecanoyl-phorbol-13-acetate (TPA) induced an increase in MMP-1 mRNA (data not shown).

Figure 7 illustrates a proposed scheme of how Mycobacterium spp could stimulate mononuclear phagocytes to upregulate the matrix metalloproteinase genes in macrophages and release human proteinases. Macrophage release of TNF- $\alpha$ and IL-1 $\beta$ can lead to fibroblast synthesis of MMP-1 which amplifies the degradation of collagen types I-IV. MMP-1 inhibits $\alpha_{1}$-antitrypsin leading to enhanced elastolytic activity with digestion of elastin and fibronectin resulting in tissue destruction, caseation necrosis, and cavity formation.

\section{Discussion}

We have shown that $M$ tuberculosis $\mathrm{H} 37 \mathrm{Ra}$ and LAM can induce the formation of the $92 \mathrm{kDa}$ gelatinase MMP-9 in THP-1 cells and the type I interstitial collagenase MMP-1 mRNA in THP-1 cells and human peripheral blood monocytes. In two patients with active cavitary tuberculosis we found striking upregulation of the MMP-9 gene in bronchoalveolar lavage cells. MMP-9 can be upregulated by peptide growth factors and cytokines in mononuclear phagocytes. ${ }^{1617}$ The induction of MMP-1 mRNA by LAM in mononuclear phagocyte cells is also considered significant for the following reasons: (a) unstimulated cells do not express the type I interstitial collagenase gen ${ }^{18}$; (b) several studies have shown that immature mononuclear phagocytes (U-937 cells and peripheral blood monocytes) under basal conditions contain predominantly neutrophil elastase and maturation of these cells into resident macrophages by phorbol ester is associated with an increased synthesis of matrix metalloproteinases which include MMP-1, MMP-2, and MMP-9, and the stromelysins

Figure 5 Northern analysis of type I interstitial collagenase gene (MMP-1) for $(A)$ two hours and (B) 24 hours with LPS $(1 \mu \mathrm{g} / \mathrm{ml})$ and LAM $(2 \mu \mathrm{g} / \mathrm{ml})$. THP-1 cells were grown to a density of $5 \times 10^{5}$ cells $/ \mathrm{ml}$ in $10 \%$ fetal calf serum and treated with stimuli for various time points. Total RNA was then isolated and an equal amount of RNA from each sample, as determined by ethidium bromide gel staining, was electrophoresed through a $1 \%$ denaturing agarose gel containing $7 \%$ formaldehyde. A $2.05 \mathrm{~kb} \mathrm{mRNA}$ transcript for $M M P-1$ was noted at two hours. Upregulation of the MMP-1 gene by LPS or LAM was seen at two hours and persisted to 24 hours. 


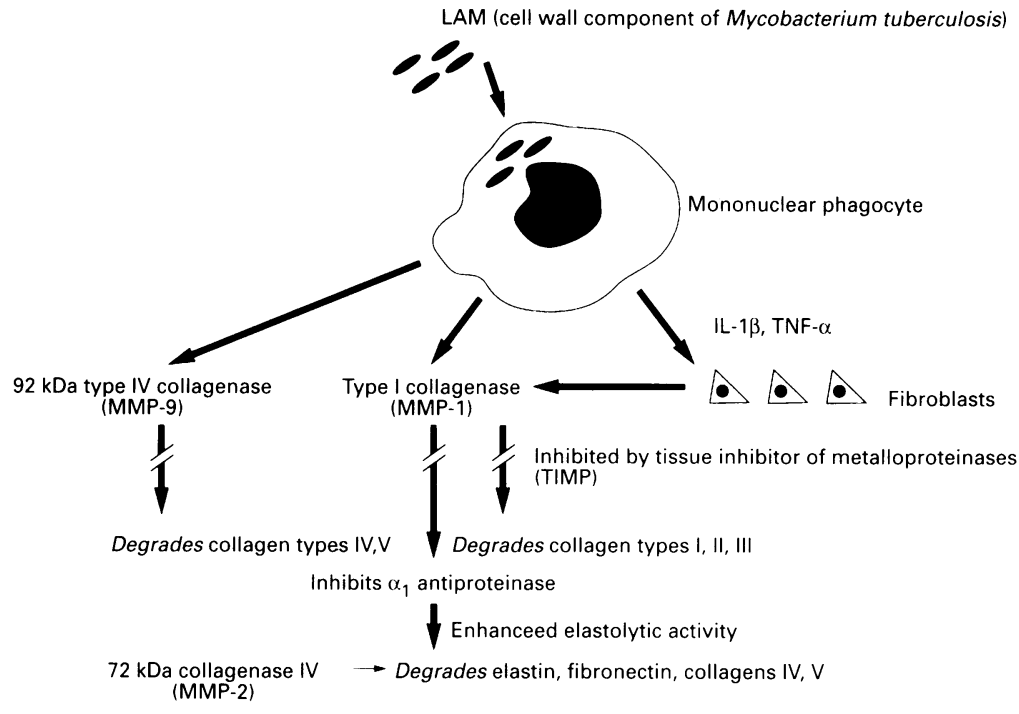

Figure 7 Scheme of proposed mechanisms of parenchymal destruction in tuberculous granuloma. LAM =lipoarabinomannan.

MMP-3, MMP-10 and MMP-11 ${ }^{19-21}$;

monocytes secrete much smaller quantities of procollagenase upon stimulation than do macrophages. ${ }^{22}$ All of the matrix metalloproteinases cleave gelatin and fibronectin at the same rate but MMP-1 is unique in its ability to cleave interstitial collagens. ${ }^{17}$ Thus, $M$ tuberculosis and LAM are potent agents for the induction of MMP-1 mRNAs and MMP9 .

LAM, the major antigenic cell wall component in Mycobacterium spp, ${ }^{7-9}$ can induce MMP-1 mRNA indirectly in human lung fibroblasts through the release of TNF- $\alpha$ and IL-1 $\beta$ from monocyte macrophages. The released collagenases may participate in the destruction of lung extracellular matrix by the following mechanism. MMP-9 can degrade several native collagens including types IV and $\mathrm{V}$. LAM stimulates mononuclear phagocytes to release IL- $1 \beta$ and TNF- $\alpha$ which stimulate lung fibroblasts to release MMP-1 as well as MMP2 and, interestingly, fibroblasts are capable of relasing greater quantities of these two MMPs. ${ }^{1617}$ MMP-1 degrades collagens I, II, III, and X and MMP-9 and MMP-2 cleave type IV basement membrane collagen. ${ }^{23}$ This initial collagenolytic cleavage of insoluble protein is essential for the subsequent endocytosis and completion of digestion within lyosomes, followed by tissue remodelling. ${ }^{45}$

In a normal physiological state metalloproteinases are tightly regulated. All of the metalloenzymes are inhibited by specific tissue inhibitors of metalloproteinases (TIMP) which are ubiquitous natural inhibitors and which form complexes with these metalloenzymes. ${ }^{524}$ In pulmonary tuberculosis, however, the regulatory mechanism of collagenases is likely to be altered in favour of collagenase activity. TNF$\alpha$ and IL- $1 \beta$ stimulate MMP gene expression ${ }^{17}$ but do not affect the level of TIMP. ${ }^{25}$ This is in contrast to the effect of TPA which stimulates both collagenase and TIMP in skin fibroblasts. ${ }^{26}$ In addition to collagenolytic activity, MMP-1 has been shown to express serpinase activity - that is, to hydrolyse and inactivate the two major serine proteinase inhibitors found in plasma, $x_{1}$-proteinase inhibitor $\left(x_{1} \mathrm{PI}\right)$ and $x_{1}$ antichymotrypsin. ${ }^{27}$ Since $\alpha_{1} \mathrm{PI}$ is the major inhibitor of elastase, in the microenvironment where human collagenases are present elastase activity would be relatively uninhibited, resulting in further destruction of lung parenchyma.

All of the MMPs are expressed and secreted by human mononuclear phagocytes in response to stimuli. ${ }^{1617202228}$ There are 11 members of the MMP family known as endopeptidases including interstitial collagenases, stromelysins, and gelatinases. ${ }^{17}$ Both MMP-1 and MMP-9 contain AP-1 binding sites in their $5^{\prime}$ DNA promoters that respond to phorbol esters and the cytokines TNF- $\alpha$ and IL-1 $\beta$ through activation of the jun gene. ${ }^{1729}$ MMP-9 is readily secreted by monocytes. ${ }^{16}$ It has been referred to as type IV collagenase and is capable of degrading not only basement membrane collagens (type IV collagen) but also elastin. ${ }^{28}$ Thus, in the presence of uninhibited matrix metalloproteinases, the destructionof lung matrix is the sum of collagenolytic and elastolytic activities. We propose that $M$ tuberculosis and its major cell wall antigen LAM play an important part in the pathogenesis of lung damage associated with pulmonary tuberculosis through the stimulation and release of collagenases by mononuclear phagocytes and, indirectly, by fibroblasts.

The authors acknowledge the Suntory Institute of Biomedical Research, Osaka, Japan for recombinant TNF- $x$, Dr P Brennan, Colorado State University, Fort Collins, Colorado, USA for LAM, Natalie Little for editorial assistance, and grants GCRC MO1 RR00096, NIH AI 32233, HL-51494, NR 03212, Heiser Foundation, Stony Wold Herbert Foundation, and Aaron Diamond Foundation for support.

1 Chang JC, Jagirdar J, Lesser M. Long-term evolution of BCG- and CFA-induced granulomas in rat lungs. $A m \mathcal{F}$ Pathol 1986;125:16-27.

2 Dannenberg AM Jr. Cellular hypersensitivity and cellular immunity in the pathogenesis of tuberculosis: specificity, systemic and local nature, and associated macrophage enzymes. Bacteriol Rev 1968;32:85-102.

3 Dannenberg AM Jr. Pathogenesis of pulmonary tuberculosis. Am Rev Respir Dis 1982;125:25-30.

4 Werb Z, Banda MJ, Jones PA. Degradation of connective tissue matrices by macrophages. F Exp Med 1980;152 $1340-57$

5 Reynolds JJ. The molecular and cellular interactions involved in connective tissue destruction. $\mathrm{Br} \mathcal{F}$ Dermatol 1985;112:715-23.

6 Hunter SW, Brennan PJ. Evidence for the presence of a phosphatidylinositol anchor on the lipoarabinomannan and lipomannan of Mycobacterium tuberculosis. 7 Biol Chem 1990;265:9272-9.

7 Chatteriee D, Roberts AD, Lowell K, Brennan PJ, Orme IM. Structural basis of capacity of lipoarabinomannan to induce secretion of tumor necrosis factor. Infect Immun 1992;60:1249-53

8 Zhang Y, Doerfler M, Lee TC, Guillemin B, Rom WN Mechanisms of stimulation of interleukin-1 $\beta$ and tumor necrosis factor- $\alpha$ by Mycobacterium tuberculosis and its components. F Clin Invest 1993;91:2076-83.

9 Barnes PF, Chatterjee D, Abrams JS, Lu S, Wang E, Yamamura $\mathbf{M}$, et al. Cytokine production induced by Mycobacterium tuberculosis lipoarabinomannan. Relationship to chemical structure. F Immunol 1992;149:541-7.

10 Wallis RS, Amir-Tahmasseb M, Ellner JJ. Induction of interleukin 1 and tumor necrosis factor by mycobacterial proteins: the monocyte Western blot. Proc Natl Acad Sci proteins: the monocyte
USA $1990 ; 87: 3348-52$

11 Takashima T, Ueta C, Tsuyuguchi I, Kishimoto S. Production of tumor necrosis factor alpha by monocytes from p8:3286-92.

12 Moreno C, Taverne J, Mehlert A, Bate CAW, Brealey RJ, Meager A, et al. Lipoarabinomannan from $M$ tuberculosis induces the production of tumor necrosis factor from human and murine macrophages. Clin Exp Immunol 1989 76:240-5. 
13 Chensue SW, Davey MP, Resnick DG, Kunkel SL. Release of interleukin-1 by peripheral blood mononuclear cells in patients with tuberculosis and active inflammation. Infect Immun 1986;52:341-3.

14 Dayer J-M, Beutler B, Cerami A. Cachectin/tumor necrosis factor stimulates collagenase and prostaglandin $E_{2}$ production by human synovial cells and dermal fibroblasts. duction by human synovial cell

15 Dayer J-M, de Rochemonteix B, Demczuk S, Dinarello CA Human recombinant interleukin 1 stimulates collagenase and prostaglandin $\mathrm{E}_{2}$ production by human synovial cells. f Clin Invest 1986;77:645-8.

16 Welgus HG, Campbell EJ, Cury JD, Eisen AZ, Senior RM, Wilhelm SM, et al. Neutral metalloproteinases produced by human mononuclear phagocytes: enzyme profile, regulation, and expression during cellular development. $\mathcal{F}$ Clin Invest 1990;86:1496-502.

17 Birkedal-Hansen H, Moore WGI, Bodden MK, Windsor LJ, Birkedal-Hansen B, DeCarlo A, et al. Matrix metalloproteinases: a review. Crit Rev Oral Biol Med 1993;4: 197-250.

18 Bar-Shavit Z, Teitelbaum SL, Stricklin GP, Eisen AZ, Kahn AJ, Welgus HG. Differentiation of a human leukemia cell line and expression of collagenase inhibitor. Proc Natl Acad Sci USA 1985;82:5380-4.

19 Senior RM, Campbell EJ, Landis JA, Cox FR, Kuhn C, Koren HS. Elastase of U-937 monocytelike cells: comparisons with elastases derived from human monocytes and neutrophils and murine macrophagelike cells. $\mathcal{f}$ Clin Invest 1982;69:384-93.

20 Welgus HG, Connolly NL, Senior RM. 12-0-Tetradecanoyl-phorbol-13-acetate-differentiated U9327 cells express a macrophage-like profile of neutral proteinases: high levels of secreted collagenase and collagenase inhibitor accompany low levels of intracellular elastase and cathepsin G. $\mathcal{F}$ Clin Invest 1986;77:1675-81

21 Hersh CL, Yeh RK, Callaway JE, Garcia JA Jr, GilmoreHebers $M$. Induction of collagenase production in U937 cells by phorbol ester and partial purification of the induced enzyme. Biochemistry 1986;25:2750-7.

22 Campbell EJ, Cury JD, Lazarus CJ, Welgus HG. Monocyte procollagenase and tissue inhibitor of metalloproteinases. f Biol Chem 1987;262:15862-8.

23 Welgus HG, Fliszar CJ, Seltzer JL, Schmid TM, Jeffrey JJ. Differential susceptibility of type $\mathrm{X}$ collagen to cleavage by two mammalian interstitial collagenases and $72-\mathrm{kDa}$ type IV collagenase. $\mathcal{f}$ Biol Chem 1990;265:13521-7.

24 Matrisian LM. Metalloproteinases and their inhibitors in matrix remodeling. Trends Genet 1990;6:121-5.

25 MacNaul KL, Chartrain N, Lark M, Tocci MJ, Hutchinson NI. Discoordinate expression of stromelysin, collagenase and tissue inhibitor of metalloproteinases- 1 in theumatoid human synovial fibroblasts. F Biol Chem 1990;265:1723845 .

26 Clark SD, Wilhelm SM, Stricklin GP, Welgus HG. Coregulation of collagenase and collagenase inhibitor production by phorbol myristate acetate in human skin fibroblasts. Arch Biochem Biophys 1985;241:36-44.

27 Desrochers PE, Jeffrey JJ, Weiss SJ. Interstitial collagenase (matrix metalloproteinase-1) expresses serpinase activity. $\mathfrak{f}$ Clin Invest 1991;87:2258-65.

28 Senior RM, Griffin GL, Fliszar CJ, Shapiro SD, Goldberg GI, Welgus HG. Human 92- and 72-kilodalton type IV collagenase are elastases. $f$ Biol Chem 1991:266:7870-5.

29 Brenner DA, O'Hara M, Angel P, Chojkier M, Karin M Prolonged activation of jun and collagenase genes by tumour necrosis factor- $\alpha$. Nature 1989;337:661-3. 